Jahangirnagar University J. Biol. Sci. 6(2): 1-9, 2017 (December)

\title{
Optimization of culture condition, phytoconstituents and cytotoxicity of Xylaria hypoxylon (L.) Grev.
}

\author{
Fakhruddin Ali Ahmed ${ }^{*}$ and Nusrat Jahan \\ Department of Botany, Jahangirnagar University, Savar, Dhaka-1342, Bangladesh
}

\begin{abstract}
Experiments were carried out to determine the optimum culture condition, phytochemical constituents as well as cytotoxic activity of the endophytic fungus Xylaria hypoxylon (L.) Grev. grown on rotten bamboo poles at Jahangirnagar University campus. The fungus was first identified up to the species level, then suitable growth medium under laboratory condition was ascertained. Among the different types of culture media, Potato dextrose agar (PDA) medium was found to be the most suitable for optimum growth of this fungus at $\mathrm{pH} 6$ and $30^{\circ} \mathrm{C}$. Phytochemical study of fruit body extract showed substantial presence of terpenoids, steroids, phenolic compounds, and weak presence of glycosides, falvonoids, and saponins. Brine shrimp lethality assay of the extract showed moderate cytotoxicity with $\mathrm{LC}_{50}$ value $327.00 \mu \mathrm{g} / \mathrm{ml}$ after 6 hours.
\end{abstract}

Key words: Bioactivity, culture condition, phytoconstituents, Xylaria hypoxylon.

\section{INTRODUCTION}

Fungi of the genus Xylaria are known to be a rich source of secondary metabolites namely, succinic acid derivatives (Anderson and Edwards, 1985), cytochalasin (Dagne et al., 1994) and the more common melleins (Whalley \& Edwards, 1995). The production of antifungal antibiotic Griseofulvin and dichlorogriseofulvin from Xylaria sp. strain F0010 (Park et al., 2005) were great discovery for medical science. Xylaria hypoxylon (L.) Grev., the "candle snuff fungus", is one of the most acquainted fungi of Xylariaceae family; first reported by Linnaeus (1753) with basionym Clavaria hypoxylon (Stadler et al., 2014). This fungus is widely known for causing white rot in wood and commonly found on dead wood, often on stumps or woody material buried in the soil, always in humid environments in temperate regions of the world (Chen et al., 2013). The studied fungus $X$. hypoxylon has been reported to produce novel secondary metabolites viz., Cytochalasins, epoxycytochalasin Q and R (Espada et al., 1997), a pyrone derivatives (Schüfflera et al., 2007) and tetralone derivatives (Gu \& Ding, 2008). Some of these important bioactive compounds have shown significant toxic activity against human cancer cell lines (Schüfflera et al., 2007).

There is a very few report on Xylaria in Bangladesh. Siddiqui et al. (2007) reported $X$. hypoxylon from the forests of Dhaka, Chittagong, Sylhet as well as in the village grooves of Bangladesh. Till now, no report emphasizing on cytotoxicity of secondary metabolites

\footnotetext{
*Corresponding author. Email: faahmed_ju@yahoo.com
} 
of this fungus in Bangladesh came up to view. Therefore, laboratory experiments were carried out to determine the ideal culture condition followed by assessment for phytochemicals and cytotoxicity of the fruiting body extract of $X$. hypoxylon.

\section{MATERIALS AND METHODS}

Fresh fruiting bodies of $X$. hypoxylon were collected from rotten bamboo poles from Jahangirnagar University campus, Savar, Dhaka and representative voucher specimen was properly processed and deposited at the Phytochemistry and Herbal medicine research facilities of Botany Department of Jahangirnagar University with accession no. Jahan1. The taxonomic study and identification of this species was carried out following Perŝoh et al. (2009), Fournier et al. (2011) and Stadler et al. (2014). Observation was carried out on dry material. Length and width of asci, ascospore, paraphysis were measured in teleomorphic stromata using ocular micrometer. Ascospores were examined in distilled water, and ascus plugs were stained in Melzer's reagent. Photomicrographs were taken by stereomicroscope OLYMPUS (DP72) under magnification 10x, 20x and 100x at Wazed Mia Science Research Center, Jahangirnagar University, Savar, Dhaka.

Different culture media were prepared following Koley \& Mahapatra (2015). Potato dextrose agar (PDA), Corn meal agar (CMA), Yeast-extract malt glucose agar (YMGA), Oatmeal agar (OA) and Bamboo shoot extract agar were tested to select the appropriate growth medium for the fungi. Experiments on culture condition establishment were carried out following Ahmed et al. (2013). Besides, the test fungus was grown on PDA with varying $\mathrm{pH}$ and temperature to assess its biological features. PDA medium was adjusted to different $\mathrm{pH}$ levels viz., 4.0, 5.0, 6.0, 7.0, 8.0, 9.0 and 10.0 with $1 \mathrm{~N} \mathrm{NaOH}$ or $1 \mathrm{~N} \mathrm{HCl}$ by using $\mathrm{pH}$ meter. Lower and higher temperature was provided by ice box and incubation chamber (Jouan Quality System) respectively. Methanolic crude extract was obtained by powdering 36 grams of fruit body of the fungus and soaking in a clean, flat bottom glass container in $100 \mathrm{ml}$ of $100 \%$ methanol. The mixture was kept for 4 days in dark place with occasional stirring. The eluent was filtered with Whatman no.1 filter paper and the extract was concentrated at $45^{\circ} \mathrm{C}$ temperature under reduced pressure using a rotary evaporator and resultant residue was stored under refrigerated conditions until further studies.

A portion of the crude extract was subjected to different qualitative tests to find out the presence of secondary metabolites referring to characteristic color changes using standard procedures (Trease \& Evans, 1989; Ghani, 1998; Dev, 2002). The cytotoxicity assay was carried out through brine shrimp lethality assay at 10,20,40,80,160,200 $\mu \mathrm{g} / \mathrm{ml}$ concentrations following Meyer et al. (1982). Duncan's Multiple Range Test (DMRT) was performed following the method of Steel and Torrie, (1960) using SPSS-16.0 software to weigh up the differences in growth performances of $X$. hypoxylon under variable conditions. 


\section{RESULTS AND DISCUSSION}

Xylaria Hill ex Schrank is a complex genus. Detailed descriptions on cultures as well as morphological characters of the stromata and teleomorphs are necessary to identify $X$. hypoxylon.

Xylaria hypoxylon (L.) Grev., Flora Edinensis, pp. 355 (1824).

Plate 1

Basionym: Clavaria hypoxylon L., Species Plantarum. 2: 1182 (1753).

Height of stromata ranged between $60-85 \mathrm{~mm}$, fertile part 1-2.5 mm broad and (6.5-)10$25 \mathrm{~mm}$ long. Morphologically the stromata cylindrical to slightly fusiform, terete to flattened, branched from the base and middle, arising from medium lengthed stipes (35$60 \mathrm{~mm}$ high and 1-3 mm broad). The apex of stromata always flattened to mucronate and sterile. Whitish stromata at immature state, gradually turning to dark brown to black at matured fertile state. In well-developed stromata the outer crust peeling, furrowed, leathery, black covering creamy, cheesy, solid interior.

Asci cylindrical, long stipated, unitunicate in structure, 8 spored. Spore bearing part 69$88.32 \mu \mathrm{m}$ long $\times 4.6-8.2 \mu \mathrm{m}$ broad. The apical apparatus or operculum tubular in shape with slightly wide apex bluing in Melzer's iodine reagent. Paraphysis slender, sterile, filamentous structure that surround the fertile spore bearing apparatus. In the studied sample paraphysis were sparse, hyaline, thread like with oil droplets, 90.3-102.75 $\mu \mathrm{m}$ long $\times 0.75-2 \mu \mathrm{m}$ broad.

Ascospores ellipsoid-inequilateral with narrowly to broadly rounded ends, uniseriate overlapping in ascus, olivaceous to medium brown, 11.8-16.4 $\mu \mathrm{m}$ long $\times 4.6-5.52 \mu \mathrm{m}$ broad, two guttules at matured spore, conspicuous straight to slightly curved germ slit 4/5 to nearly spore length on the flattened and rarely on the convex side. Mycelial colony appeared after 4 days incubation in PDA medium at $30^{\circ} \mathrm{C}$ showed characteristic white colony, lannose to filiform, with fine fibrous appearance in the middle and sparse cottony appearance at the edge.

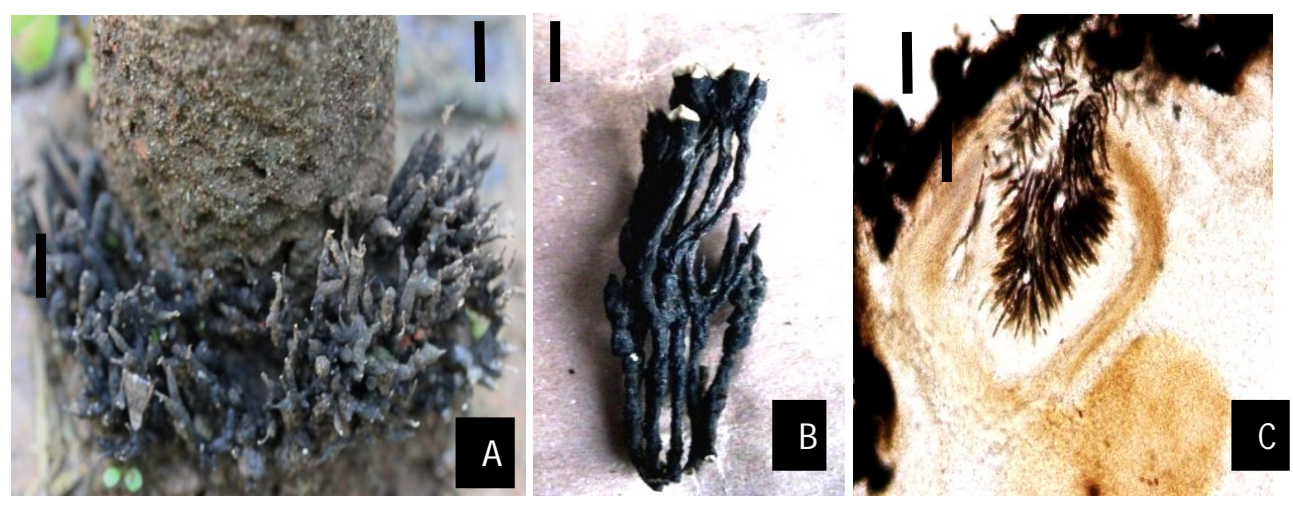



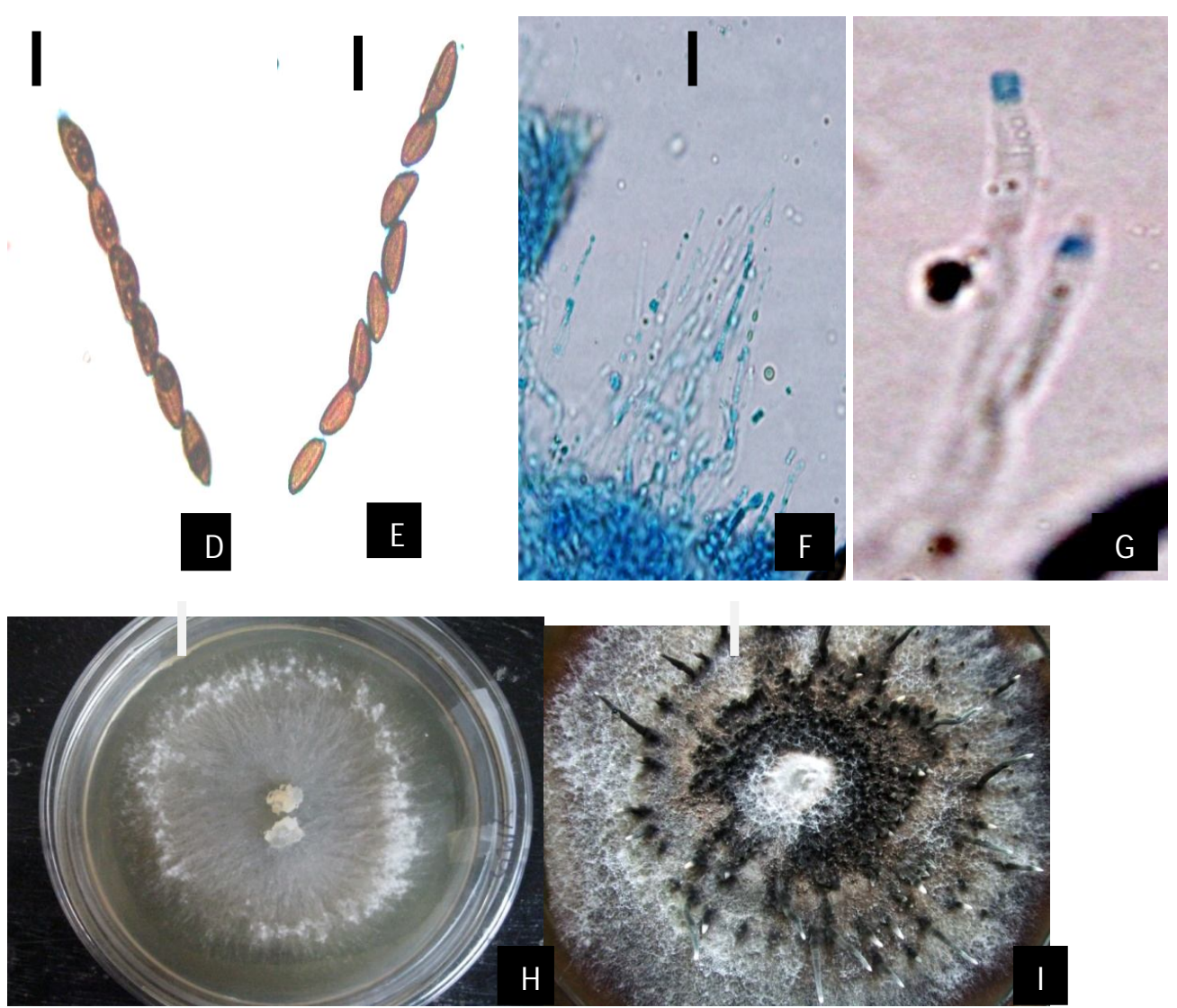

Plate 1. Xylaria hypoxylon. A. fruit body in natural habitat B. fruiting bodies with white sterile apices (6.5-) $10-30 \mathrm{~mm}$ high C. subglobose perithacia (253-402.5 $\mu \mathrm{m})$ containing ascospore. D. biguttulate ascospores (11.8-16.4 $\mu \mathrm{m}$ long $\times$ 4.6-5.52 $\mu \mathrm{m}$ broad) in ascus $(69-88.32 \mu \mathrm{m}$ long $\times$ 4.6-8.2 $\mu \mathrm{m}$ broad). E. straight germ slit up to spore length. F. paraphysis $(90.3-102.75 \mu \mathrm{m}$ long $\times$ 0.75-2 $\mu \mathrm{m}$ broad). G. Tubular operculum in immature ascus. $H$. Fungal colony in PDA medium $(9 \mathrm{~cm}$ plate). $\mathrm{I}$. Anamorphic stromata. Bars: $A, B=5 \mathrm{~mm} ; C=40 \mu \mathrm{m} ; \mathrm{D}, \mathrm{E}=\mathbf{7 . 7 4} \mu \mathrm{m} ; \mathrm{F}=\mathbf{1 4 . 3 9} \mu \mathrm{m}$; $\mathrm{H}, \mathrm{I}=1.5 \mathrm{~cm}$.

After 3 weeks of culture, abundant small stromata developed in a circular manner holding sinnematal conidiomata on the top. X. hypoxylon could easily be confused with its three closely related species $X$. longipes Nitschke, $X$. longiana Rehm and $X$. multiplex (Kunze) Fr. (Fournier et al., 2011). X. longiana is a scrawny species of Xylaria, virtually indistinguishable from $X$. hypoxylon, except for having smaller spores $(9-11 \times 4-5 \mu)$ (Kuo, 2008). Conversely stromata of $X$. hypoxylon and $X$. longipes are identical but the ascospores of $X$. longipes are (11-)13-15(-17) $\times(5-) 6(-7) \mu \mathrm{m}$, with spiraling germ slits. Despite the similarities with $X$. hypoxylon in appearance of ascospores and germ slit, stromata of $X$. multiplex first appear as dark brown to blackish with paler brown shredding outer layer in contrast to whitish stromata with black, leathery and peeling furrowed outer layer of X. hypoxylon, consistent with Rogers et al. (2008). 
Determination of laboratory culture condition for $\boldsymbol{X}$. hypoxylon: Malt extract agar, corn meal agar, potato dextrose yeast extract agar and oat meal agar are frequently used media for X. hypoxylon culture (Peršoh et al., 2009, Fournier et al., 2011 and Stadler et al., 2014). Vegetative growth of $X$. hypoxylon was investigated using some common culture media at $\mathrm{pH} 6$ and $30^{\circ} \mathrm{C}$ and has been presented in Table 1.

Table 1. Effect of different culture media on growth of the $X$. hypoxylon

\begin{tabular}{|c|c|c|c|c|c|c|c|}
\hline \multirow[t]{2}{*}{ Culture medium } & \multicolumn{7}{|c|}{ Mycelial growth $(\mathrm{cm})$ at $30^{\circ} \mathrm{C}$ temperature and $\mathrm{pH} 6.0$} \\
\hline & $2^{\text {nd }}$ day & $4^{\text {th }}$ day & $6^{\text {th }}$ day & $8^{\text {th }}$ day & $10^{\text {th }}$ day & $12^{\text {th }}$ day & $14^{\text {th }}$ day \\
\hline Potato dextrose agar (PDA) & $1.63 \mathrm{a}$ & $2.54 \mathrm{a}$ & $4.21 \mathrm{a}$ & $6.35 a$ & $7.21 \mathrm{a}$ & $7.51 \mathrm{a}$ & $8.11 \mathrm{ab}$ \\
\hline Corn meal agar (CMA) & $1.00 \mathrm{c}$ & $1.22 \mathrm{~d}$ & $1.43 \mathrm{e}$ & $2.37 \mathrm{e}$ & $4.85 \mathrm{~d}$ & $5.17 \mathrm{c}$ & $6.37 \mathrm{c}$ \\
\hline $\begin{array}{l}\text { Yeast extract malt } \\
\text { glucose agar (YMGA) }\end{array}$ & $1.25 b$ & $1.43 c$ & $2.97 \mathrm{bc}$ & $4.69 b$ & $6.37 \mathrm{~b}$ & $6.85 b$ & $7.80 \mathrm{~b}$ \\
\hline Oat meal agar (OA) & $0.78 \mathrm{~d}$ & $1.58 \mathrm{~b}$ & $2.61 b c$ & $3.97 \mathrm{c}$ & $5.92 \mathrm{c}$ & $6.11 \mathrm{~d}$ & 7.96ab \\
\hline Bamboo shoot extract agar & $0.48 \mathrm{e}$ & $0.97 \mathrm{e}$ & $1.58 \mathrm{~d}$ & $3.13 \mathrm{~d}$ & $4.26 \mathrm{e}$ & $5.25 \mathrm{c}$ & $5.98 \mathrm{~d}$ \\
\hline
\end{tabular}

Note: Data are averages of three replications. In a column means followed by the same letter are not different significantly at $5 \%$ level by DMRT.

Significant variation was observed during optimization of laboratory culture condition. After two weeks of incubation, maximum mycelial growth was observed in PDA medium $(8.11 \mathrm{~cm})$ followed by Oat meal agar medium $(7.96 \mathrm{~cm})$, yeast extract malt glucose agar medium $(7.8 \mathrm{~cm})$, corn meal agar $(6.37 \mathrm{~cm})$ and bamboo shoot agar $(5.98 \mathrm{~cm})$. Oat meal and yeast malt glucose agar (YMGA) medium showed a moderate response to the mycelia growth of the fungus (Table 1). In contrast, Callan \& Rodgers (1993) reported on growth of this fungus on $2 \%$ oat meal agar $(\mathrm{OA})$ medium and mentioned that Xylaria cultures can differ considerable in appearance on various media. Laessøe \& Lodge (1994) reported that oat meal agar, 2\% malt agar and potato dextrose agar to describe the mycelial features of Xylaria axifera.

Effect of temperature on growth of fungus was determined by growing the fungus on PDA medium at $\mathrm{pH} 6$ with varying temperature ranged between $10-35^{\circ} \mathrm{C}$. The fungus started responding on the 2 nd day of incubation. It grew $8.36 \mathrm{~cm}$ diameter at $30^{\circ} \mathrm{C}$ in 2 weeks followed by $7.35 \mathrm{~cm}\left(35^{\circ} \mathrm{C}\right), 6.41 \mathrm{~cm}\left(25^{\circ} \mathrm{C}\right), 4.97 \mathrm{~cm}\left(20^{\circ} \mathrm{C}\right)$. The lowest growth was observed at $15^{\circ} \mathrm{C}$ and no response at $10^{\circ} \mathrm{C}$. So optimum temperature for fungal growth ranged between $30-35^{\circ} \mathrm{C}$ (Table 2 ).

Table 2. Effect of temperature on mycelial growth of $X$. hypoxylon

\begin{tabular}{c|c|c|c|c|c|c|c}
\hline \multirow{2}{*}{ Temperature } & \multicolumn{7}{|c}{ Mycelial growth $(\mathrm{cm})$ at $\mathrm{pH} 6.0$ in PDA medium } \\
\cline { 2 - 8 } & $2^{\text {nd }}$ day & $4^{\text {th }}$ day & $6^{\text {th }}$ day & $8^{\text {th }}$ day & $10^{\text {th }}$ day & $12^{\text {th }}$ day & $14^{\text {th }}$ day \\
\hline $10^{\circ} \mathrm{C}$ & $0.00 \mathrm{~d}$ & $0.00 \mathrm{~d}$ & $0.00 \mathrm{f}$ & $0.00 \mathrm{e}$ & $0.00 \mathrm{f}$ & $0.00 \mathrm{f}$ & $0.00 \mathrm{f}$ \\
$15^{\circ} \mathrm{C}$ & $0.00 \mathrm{~d}$ & $0.13 \mathrm{~cd}$ & $0.42 \mathrm{e}$ & $1.21 \mathrm{~d}$ & $1.68 \mathrm{e}$ & $2.33 \mathrm{~d}$ & $2.54 \mathrm{e}$ \\
$20^{\circ} \mathrm{C}$ & $0.31 \mathrm{c}$ & $0.67 \mathrm{c}$ & $1.56 \mathrm{~d}$ & $2.75 \mathrm{c}$ & $3.09 \mathrm{~d}$ & $3.74 \mathrm{~d}$ & $4.97 \mathrm{~d}$ \\
$25^{\circ} \mathrm{C}$ & $0.69 \mathrm{~b}$ & $1.66 \mathrm{~b}$ & $2.42 \mathrm{c}$ & $3.13 \mathrm{bc}$ & $4.73 \mathrm{c}$ & $5.79 \mathrm{c}$ & $6.41 \mathrm{c}$ \\
$30^{\circ} \mathrm{C}$ & $1.52 \mathrm{a}$ & $2.47 \mathrm{a}$ & $4.36 \mathrm{~b}$ & $6.40 \mathrm{a}$ & $7.29 \mathrm{ab}$ & $7.68 \mathrm{a}$ & $8.36 \mathrm{a}$ \\
$35^{\circ} \mathrm{C}$ & $1.83 \mathrm{a}$ & $2.89 \mathrm{a}$ & $5.78 \mathrm{a}$ & $6.19 \mathrm{a}$ & $6.96 \mathrm{~b}$ & $7.11 \mathrm{~b}$ & $7.35 \mathrm{~b}$ \\
\hline
\end{tabular}

Note: Data are averages of three replications. In a column means followed by the same letter are not different significantly at $5 \%$ level by DMRT. 
During two weeks of incubation, $X$. hypoxylon showed consistent growth from $\mathrm{pH} 5$ to 10. The fungus started responding after 2 days of inoculation. Statistically significant growth was observed in $\mathrm{pH} 6(8.80 \mathrm{~cm}), 5(8.50 \mathrm{~cm})$ and $7(8.60)$ followed by $\mathrm{pH} 8(7.80$ $\mathrm{cm}), 9(7.30 \mathrm{~cm})$ and $10(7.20 \mathrm{~cm})$ respectively (Table 3$)$. The optimum $\mathrm{pH}$ for growth ranged between 5 and 7 . Thus the optimum culture condition for $X$. hypoxylon may be PDA medium or oat meal agar with $\mathrm{pH} 5$ to 7 and $30^{\circ}$ to $35^{\circ} \mathrm{C}$ temperature.

Table 3. Effect of pH on growth of $X$. hypoxylon on PDA medium

\begin{tabular}{c|c|c|c|c|c|c|c}
\hline \multirow{2}{*}{$\begin{array}{c}\text { pH of } \\
\text { medium }\end{array}$} & \multicolumn{7}{|c}{ Mycelium growth $(\mathrm{cm})$ at $30^{\circ} \mathrm{C}$} \\
\cline { 2 - 8 } & $2^{\text {nd }}$ day & $4^{\text {th }}$ day & $6^{\text {th }}$ day & $8^{\text {th }}$ day & $10^{\text {th }}$ day & $12^{\text {th }}$ day & $14^{\text {th }}$ day \\
\hline 4 & $0.00 \mathrm{c}$ & $0.00 \mathrm{e}$ & $0.00 \mathrm{~d}$ & $0.00 \mathrm{~d}$ & $0.00 \mathrm{~d}$ & $0.00 \mathrm{~d}$ & $0.00 \mathrm{c}$ \\
5 & $1.63 \mathrm{~b}$ & $2.54 \mathrm{~cd}$ & $4.21 \mathrm{~b}$ & $6.35 \mathrm{a}$ & $7.21 \mathrm{ab}$ & $7.51 \mathrm{~b}$ & $8.50 \mathrm{a}$ \\
6 & $2.12 \mathrm{ab}$ & $3.47 \mathrm{a}$ & $5.67 \mathrm{a}$ & $6.63 \mathrm{a}$ & $7.45 \mathrm{ab}$ & $7.90 \mathrm{a}$ & $8.80 \mathrm{a}$ \\
7 & $1.98 \mathrm{ab}$ & $2.92 \mathrm{~b}$ & $5.11 \mathrm{a}$ & $6.48 \mathrm{a}$ & $7.30 \mathrm{ab}$ & $7.75 \mathrm{ab}$ & $8.60 \mathrm{a}$ \\
8 & $1.60 \mathrm{~b}$ & $2.37 \mathrm{c}$ & $3.95 \mathrm{~b}$ & $5.12 \mathrm{~b}$ & $6.00 \mathrm{c}$ & $6.22 \mathrm{c}$ & $7.80 \mathrm{~b}$ \\
9 & $1.54 \mathrm{~b}$ & $2.25 \mathrm{c}$ & $3.35 \mathrm{c}$ & $4.52 \mathrm{c}$ & $5.94 \mathrm{c}$ & $6.45 \mathrm{c}$ & $7.30 \mathrm{~b}$ \\
10 & $1.12 \mathrm{ab}$ & $2.20 \mathrm{~b}$ & $3.28 \mathrm{a}$ & $4.48 \mathrm{a}$ & $5.30 \mathrm{ab}$ & $6.25 \mathrm{ab}$ & $7.20 \mathrm{a}$ \\
\hline
\end{tabular}

Note: Data are averages of three replications. In a column means followed by the same letter are not different significantly at $5 \%$ level by DMRT.

Phytochemical screening: Crude methanolic extract of $X$. hypoxylon showed strong presence of terpenoids, steroids and phenolic substances and weak presence of carbohydrates, tannins and flavonoids. Alkaloids and saponins were moderately present in the extract (Table 4). Adeduntan \& Adeniyi (2014) reported a weak presence of tannin in $X$. hypoxylon. Moderate presence of alkaloids was supported by the findings of Espada et al (1997). Strong presence of terpeniods in the fruit body extract of $X$. hypoxylon can be correlated with the findings of Deyrup et al. (2007) where he mentioned the isolation of triterpenoid glycosides from Xylaria sp.

Brine shrimp lethality bioassay was carried out to determine the cytotoxicity of fruit body extract of $X$. hypoxylon at different concentration.

Table 4. Qualitative chemical screening of fruiting body extract of $X$. hypoxylon

\begin{tabular}{l|l|l|c}
\hline $\begin{array}{l}\text { Sl. } \\
\text { No. }\end{array}$ & phytochemicals & Name of the test & $\begin{array}{c}\text { Extract of } X . \\
\text { hypoxylon }\end{array}$ \\
\hline 1 & Carbohydrates & Molish's test & + \\
& & Fehling reagent & + \\
\hline 2 & Alkaloids & Wagner's reagent & ++ \\
& & Mayer's reagent & + \\
& & Dragendorff's reagent & ++ \\
\hline 3 & Glycosides & Tannic acid solution 10\% & - \\
& a. Cardiac glycosides & FeCl Kest $_{3}$ teller Killiani's test & - \\
& b. Anthraquinone glycosides & Borntrager's test & + \\
\hline 4 & Flavonoids & Lead acetate test & - \\
& & Alkali test & - \\
\hline
\end{tabular}




\begin{tabular}{lllc} 
& & $\mathrm{Conc}_{2} \mathrm{H}_{2} \mathrm{SO}_{4}$ & + \\
\hline 5 & Tannins & $\mathrm{FeCl}_{3}+\mathrm{MeOH}$ extract & + \\
\hline 6 & Terpenoids & & \\
& a. Terpene & $\mathrm{CHCl}_{3}+\mathrm{H}_{2} \mathrm{SO}_{4}$ & ++ \\
& b. Triterpene & $\mathrm{CHCl}_{3}+$ Acetic anhydride & +++ \\
\hline 7 & Steroids & $\mathrm{Salkowski} \mathrm{test}$ & +++ \\
\hline 8 & Phenols & $\mathrm{FeCl}_{3}$ test & +++ \\
& & $\mathrm{Ammonia}$ & + \\
& & Lead acetate test & +++ \\
\hline 9 & Saponins & Foam test & ++ \\
\hline
\end{tabular}

Note: $+++=$ strong reaction, $++=$ moderate reaction, $+=$ weak reaction, $-=$ nil $/$ no reaction

Table 5. Brine shrimp lethality assay of crude extract of $X$. hypoxylon

\begin{tabular}{|c|c|c|c|c|c|c|}
\hline $\begin{array}{l}\text { Counting } \\
\text { time }\end{array}$ & $\begin{array}{c}\text { Sample } \\
\text { concentration } \\
(\mu \mathrm{g} / \mathrm{ml})\end{array}$ & Log conc. & $\begin{array}{c}\text { Mortality } \\
(\%)\end{array}$ & $\begin{array}{c}\mathrm{LC}_{50} \\
\mu \mathrm{g} / \mathrm{ml}\end{array}$ & $\begin{array}{c}\mathrm{LC}_{90} \\
\mu \mathrm{g} / \mathrm{ml}\end{array}$ & $\begin{array}{c}\mathrm{LC}_{50} \text { of } \\
\text { vincristine } \\
\text { sulphate }\end{array}$ \\
\hline \multirow{7}{*}{$6 \mathrm{hrs}}$. & Control & 0 & 0 & \multirow{7}{*}{327.00} & \multirow{7}{*}{572.49} & \multirow{7}{*}{0.0699} \\
\hline & 10 & 1 & 0 & & & \\
\hline & 20 & 1.301 & 0 & & & \\
\hline & 40 & 1.601 & 3.33 & & & \\
\hline & 80 & 1.903 & 6.66 & & & \\
\hline & 160 & 2.203 & 23.33 & & & \\
\hline & 200 & 2.301 & 30 & & & \\
\hline \multirow{7}{*}{$12 \mathrm{hrs}$. } & Control & 0 & 0 & \multirow{7}{*}{107.28} & \multirow{7}{*}{191.49} & \multirow{7}{*}{0.031} \\
\hline & 10 & 1 & 0 & & & \\
\hline & 20 & 1.301 & 3.33 & & & \\
\hline & 40 & 1.601 & 20 & & & \\
\hline & 80 & 1.903 & 46.66 & & & \\
\hline & 160 & 2.203 & 80 & & & \\
\hline & 200 & 2.301 & 86.66 & & & \\
\hline \multirow{7}{*}{24 hrs. } & Control & 0 & 0 & \multirow{7}{*}{85.09} & \multirow{7}{*}{165.72} & \multirow{7}{*}{0.009} \\
\hline & 10 & 1 & 3.33 & & & \\
\hline & 20 & 1.301 & 10 & & & \\
\hline & 40 & 1.601 & 26.66 & & & \\
\hline & 80 & 1.903 & 76.66 & & & \\
\hline & 160 & 2.203 & 83.33 & & & \\
\hline & 200 & 2.301 & 100 & & & \\
\hline
\end{tabular}

Kamuhabwa et al. (2000) and Schüfflera et al. (2007) reported the production of tetralone derivative xylariol A, B and xylarone in $X$. hypoxylon respectively which indicated cytotoxicity against HepG2 and various cancer cell lines. As crude methanolic extract contain most of the compounds thus the cumulative effect of all the compounds might have shown comparatively higher cytotoxicity. Cytochalasins, cytochalasin Q; 19, 20 epoxycytochalasin Q and R (Espada et al., 1997), tetralone derivatives xylariol A and B (Gu et al., 2008), $\alpha$ pyrone derivatives xylarone and 8, 9-dehydroxyxylarone (Schüfflera et al., 2007) have been isolated from different strains of $X$. hypoxylon. Secondary 
metabolites from Xylaria proved to be valuable drugs for human health worldwide (Ramesh et al., 2012). Bangladesh drug industries may provide prospective facilities for intensive research in this aspect and may become benefited with the findings. So there is a large room for extensive research on this fungus and its allied species.

Acknowledgment: This research work was supported by the University Grants Commission (UGC) research fund in 2015-2016 fiscal year, which is gratefully acknowledged. Authors also wish to concede the laboratory support given by the Plant Pathology and Plant Protection laboratory, Department of Botany, JU in terms of research facilities.

\section{REFERENCES}

Adeduntan and Adeniyi, S. 2014. Nutritional and antinutritional characteristics of some dominant fungi species in South Western Nigeria. Int. J. Engin. Sci. 3: 18-24.

Ahmed, F.A., Alam N. and Khair, A. 2013. Incidence and biology of Corynespora cassiicola (Berk. \& Curt.) Wei. Disease of okra in Bangladesh. Bangladesh J. Bot. 42: 265-272.

Anderson, J.R. and Edwards, R.L. 1985. Metabolites of the higher fungi, Part 22. 2-Butyl-3methylsuccinic acid and 2-hexyliden-3-methylsuccinic acid from xylariaceous fungi. $J$. Chem. Soc. Perkin Trans. 7:1481-1485.

Callan, B.E. and Rogers, J.D. 1993. A synoptic key to Xylaria species from continental United States and Canada based on cultural and anamorphic features. Mycotaxon, XLVI: 141-154.

Chacko, R.J. and Rogers, J.D. 1981. Cultural Characteristics of Some Species of Xylaria. Mycologia, 73(3): 415-428.

Chen, J., Zhang, L.C., Xing, Y.M., Wang, Y.Q., Xing, X.K., Zhang, D.W., Liang, H.Q. and Guo, S.X. 2013. Diversity and taxonomy of endophytic xylariaceous fungi from medicinal plants of Dendrobium (Orchidaceae). PLoS ONE, 8: e58268.

Dagne, E., Gunatilaka, A.A.L., Asmellash, S., Abate, D., Kingston, D.G.I., Hoffmann, G.A. and Johnson, R.K. 1994. Two new cytotoxic cytochalasins from Xylaria obovata. Tetrahedron, 50: $5615-5620$.

Dev, H.S. 2002. Text Book of Pharmacognosy, $\mathbf{2}^{\text {nd }}$ edn. Acharcha press, New Delhi. pp 342.

Deyrup, S.T., Gloer, J.B., O'Donnell, K., and Wicklow, D.T. 2007. Kolokosides A-D: Triterpenoid Glycosides from a Hawaiian Isolate of Xylaria sp. J. Nat. Prod. 70: 378382.

Espada, A., Rivera, A., Fuente, D.L., Rodríguez, H. and Elson, S.W. 1997. New cytochalasins from the fungus Xylaria hypoxylon. Tetrahedron, 53: 6485-6492

Fournier, J., Flessa, F., Peršoh, D. and Stadler, M. 2011. Three new Xylaria species from southwestern Europe. Mycological Progress 10: 33-52.

Ghani, A. 1998. Medicinal plants of Bangladeh, $3^{\text {rd }}$ edn. The Asiatic society, Dhaka, Bangladesh. pp 1-17, 21.

Greville, R.K. 1824. Flora Edinensis. Pub. William Blackwood, Edinburgh. pp. 355.

$\mathrm{Gu}$, W. and Ding, H. 2008. Two new tetralone derivatives fron the culture of Xylaria hypoxylon AT-028. Chin. Chem. Lett. 19: 1323-1326.

Kamuhabwa, A., Nshimo, C. and de Witte, P. 2000. Cytotoxicity of some medicinal plant extracts used in Tanzanian traditional medicine. J. Ethnopharm.70:143-149.

Koley, S. and Mahapatra, S.S. 2015. Evaluation of culture media for growth characteristics of Alternaria solani, causing early blight of Tomato. J. Plant Pathol. Microbiol. S1: 005. doi:10.4172/2157-7471.S1-005. 
Kuo, M. 2008. Xylaria longiana. Retrieved from the MushroomExpert.Com Web site: http://www.mushroomexpert.com/xylaria_longiana.html.

Linnaeus, C. 1753. Species Plantarum. Pub. Salvius, Stockholm, 2: 1182.

Meyer, B.N., Ferrigni, N., Putnam, J.E., Jacobsen, L.B., Nichols, D.E. and McLaughlin, J.L. 1982. Brine shrimp: a convenient general bioassay for active plant constituents. Planta. Med. 45: 31-34.

Park, J.H., Choi, G.J., Lee, H.B., Kim, K.M., Jung, H.S. and Lee, S.W. 2005. Griseofulvin from Xylaria sp. strain F0010 and endophytic fungus of Abiesholophylla and its antifungal activity against plant pathogenic fungi. J. Microbiol. Biotech. 15: 112-117.

Peršoh, D., Melcher, M., Graf, K., Fournier, J. and Rambold, G. 2009. Molecular and morphological evidence for the delimitation of Xylaria hypoxylon. Mycologia, 101: 256268.

Ramesh V., Santosh K., Anand T.D., Shanmugaiah V., Kotamraju S., Karunakaran C. and Rajendran A. 2015. Novel bioactive wild medicinal mushroom-Xylaria sp. R006 (Ascomycetes) against multidrug resistant human bacterial pathogens and human cancer cell lines. Int. J. Med. Mushrooms, 17: 1005-1017.

Rogers, J.D. 1979. The Xylariaceae: Systematic, Biological and Evolutionary Aspects. Mycologia, 71:1-42.

Rogers, J.D., Miller, A.N. and Vasilyeva, L.N. 2008. Pyrenomycetes of the Great Smoky Mountains national park. VI. Kretzschmaria, Nemania, Rosellinia and Xylaria (Xylariaceae). Fungal Diversity, 29: 107-116.

Schüfflera, A., Sternerb, O., and Ankea, H. 2007. Cytotoxic $\alpha$-Pyrones from Xylaria hypoxylon. Ins. Biotech. Drug. Res. 62: 169-172.

Siddiqui, K.U., Islam, M.A., Ahmed, J.U., Begum, Z.N.T., Hassan, M.A., Khondoker, M., Rahman, M.M., Kabir, S.M.H., Ahmad, M., Ahmed, A.T.A., Rahman, A.K.A. and Haque, E.U. (eds). 2007. Encyclopedia of Flora and Fauna of Bangladesh. Cyanobacteria, Bacteria and Fungi. Asiatic Society of Bangladesh, Dhaka. 2: 360-361.

Stadler, M., David, L., Hawksworth, and Fournier, J. 2014. The application of the name Xylaria hypoxylon, based on Clavaria hypoxylon of Linnaeus. IMA Fungus. 5: 57-66.

Steel, R.G.D and Torrie, J.H. 1960. Principles and procedures of statistics. McGraw Hill Book Company, New York.

Trease, G.E. and Evans, W.C. 1989. Trease and Evan's Text Book of Pharmacognosy. $13^{\text {th }}$ edn. Cambridge University press, London. pp 564.

Whalley, A. J. S., Edwards, R. L. 1995. Secondary metabolites and systematic arrangement within the Xylariaceae. Canad. J. of Bot. 73: 802-810. 